\title{
SEARCH FOR THE BEST POWER CONTROL PROGRAM AT NPP WITH VVER-1000 USING GRADIENT DESCENT METHOD
}

\author{
Pelykh S.N. ${ }^{1}$, prof., doctor of science, Odrehovska E.A. ${ }^{2}$, postgraduate student, Maksymova O.B. ${ }^{3}$, PhD., docent \\ ${ }^{1,2}$ Odessa National Polytechnic University, Odessa \\ ${ }^{3}$ Odessa National Academy of Food Technologies, Odessa \\ E-mail: ${ }^{1}$ pelykh@i.ua, ${ }^{2}$ jenia1991@i.ua, ${ }^{3}$ m.oxana.b@gmail.com
}

Copyright (C) 2014 by author and the journal "Automation technological and business - processes". This work is licensed under the Creative Commons Attribution International License (CC BY). http://creativecommons.org/licenses/by/4.0/

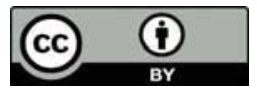

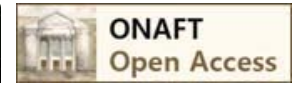

\begin{abstract}
This article is regarded to the search for the best power control program at nuclear power plant (NPP) with VVER1000 by gradient descent method for the objective function, which includes the criteria of efficiency, safety and damage. Criteria normalization to the maximum value is carried out when looking for the minimum of the objective function because criteria have different physical nature. There were chosen such objective criteria as depth of fuel burn-up, index of the fuel cladding damage and axial offset - the ratio of the energy at the top and bottom of the reactor core.
\end{abstract}

Key words

Power control program, the gradient method, the objective optimization function.

Overview the problem`s current state

Analysis of publicly available material showed that the problem of finding the best power control program at NPP with VVER-1000 for operating the unit in partly variable place the electrical load chart is reduced to two mutually sequential tasks. The first task is to simulate different power control programs of NPP with VVER-1000. Such modeling tasks were given in $[1,2]$, but a comparison of the results showed a clear advantage of only one control program presented in [3]. Such a result was a purpose response of the designed study, simulation was conducted on a relatively small time interval - one day [1,2]. For a correct comparison of the different control programs they should be modeled with the same external disturbances with full fuel campaign. Therefore, in further comparing and finding the best control program it is needed to be taken this into account and carry out a complete simulation cycle on time interval corresponding to a complete TVS burn-up [4]. The second task is to apply the standard method of finding best values of the objective function that is monotone and continuous on the accepted domain of the arguments under consideration. Gradient method can be attributed to such a kind of method.

In [5] with the method of gradient descent the optimum point trajectory of the search was found at two- and threeparameter optimization, moreover it was found that an increase in the order of regression equation increases the value of solar cells efficiency. Method of quickest descent can be used to solve systems of linearized unsteady Navier-Stokes equations with constraints on the management and unbounded set of solutions [6]. What is more, with the gradient method coordination of vertically arranged sub-systems in the equipment of agricultural enterprises [7] was optimized.

Objective

To find the best possible power control program at NPP with VVER-1000 at the current operating moment for the full time interval fuel burning by changing the Automatic Process Control System (APCS) equipment structure which can ensure the formation of a variety control programs by switching the equipment.

Main material

Calculation methods and models for existing control programs [8,9] are used as a basis for developing optimization objective. Criteria optimization objective will be: the depth of fuel burn-up, which characterizes the effectiveness of "the more, the better"; axial offset, characterizing safety "less deviates from the regulatory requirements, the better" and index of fuel 
damage "less damage, the better." There are various methods and algorithms to calculate the optimal value of the function of many variables such as the method of descent, gradient method (steepest) descent, method of ravines.

Gradient descent method was the most reasonable, because it appropriated the conditions of the problem. In this case the conditions of applicability of the method such as differentiable function and dependence on variable scale selection were taken into account. For example, if the function that is minimized too extended in space, then the procedure steepest descent converges very slowly or may not come together for a certain period of time. In this case, the problem is solved using zoom variables.

The method under consideration has a significant advantage. It is high speed. This problem belongs to the class of multicriteria optimization. To determine the type of objective function optimization it is prudent to use the method of target programming, the main purpose of which is to make decisions under conditions with many purposes.

Objective criteria that are part of the objective function are as different by more than one degree and have different metrics, so it is necessary, first of all, to carry out their normalization.

According to [10] was accepted that the maximum possible value burn-up $B_{\text {max }}$ is $45 \mathrm{MW} \mathrm{d} / \mathrm{kg}$ of uranium, so its normalized value was defined as:

where

$$
\begin{array}{r}
B_{\mathrm{n}}=B_{\text {cur }}^{i, j} / B_{\text {Max }}, \\
B_{\text {cur }}^{i, j}=\int_{0}^{t} Q_{i, j} d t,
\end{array}
$$

where $Q_{i, j}$ - the energy of one fuel assembly is determined by the model [10].

Index of the fuel cladding damage $\omega$ does not need to be normalized as it on the value [10] is in the range from 0 to 1 .

The maximum value of the axial offset AO is 6 relative units, due to the fact that it falls in the recommended area, established by the Regulations [11]. The normalized value is calculated by

$$
A O_{\mathrm{n}}=A O_{\text {cur }} / A O_{\text {мах }}
$$

A proper value of $A O_{\text {cur }}$ is defined as

$$
A O_{\text {cur }}=\frac{Q_{\mathrm{up}}-Q_{l}}{Q_{\mathrm{up}}+Q_{l}} \cdot 100 \%,
$$

where $Q_{\text {up }}$ - heat output (the energy) of the upper half of the reactor core, $\mathrm{MW}$;

$Q_{l}$ - heat output (the energy) of the lower half of the reactor core, MW.

It is known that one of the conditions under which the optimization problem can be formulated and solved, is the presence of a single, well-articulated and quantified optimality criterion in the form of the objective function.

In the context of many of the goals and limited resources, not all objectives can be achieved. In the target programming it provides the opportunity for reflection it introduces a new type of variable, indicating the degree of deviation of the achieved level of the required objectives.

Given the above, the objective function will look like:

$$
J=\sqrt{\kappa_{1}\left(B_{n}-B^{\prime}\right)^{2}+\kappa_{2}\left(\omega-\omega^{\prime}\right)^{2}+\kappa_{3}\left(A O_{n}-A O^{\prime}\right)^{2}}
$$

where $B^{\prime}, \omega^{\prime}, A O^{\prime}$ - normalized objectives values of each criterion;

$\kappa_{1}, \kappa_{2}, \kappa_{3}-$ weight coefficients.

Within the framework of the problem, normalized values of the following objectives are: $B^{\prime}=1$ as it is carried out the search of the maximum burn-up value, $\omega^{\prime}=0$ as it is carried out the search of the minimum fuel damage value; $A O^{\prime}=0$ as it is carried out the search of the minimum deviation from the set axial offset value. In terms of reliability and safe operation of nuclear power units, the values of the last two indicated values must be strictly regulatory ranges.

Further, the expression (1) can be simplified by deleting the zero objectives and substituting into equation (2) only the normalized values:

$$
J=\sqrt{\kappa_{1}(B-1)^{2}+\kappa_{2} \cdot \omega^{2}+\kappa_{3} \cdot A O^{2}}
$$

Thus, the decision of the objective optimization function would be to minimize the functional $J$ :

$$
J(B, \omega, A O) \rightarrow \min _{B \in R, \omega \in R, A O \in R}
$$

Having solved the task, it will be possible to talk about the notion of "effective operation", that is the decision that combines three incompatible components but, nevertheless, "useful" in terms of reliability and economic benefits. This decision from the point of view of multi-criteria optimization problems is called Pareto-optimal.

Analysis $[8,9]$ made it possible to identify the arguments for each of the criteria:

$$
B=\left[t_{\text {coolent }}^{\text {inlet }} ; n ; \tau_{\text {operational }}\right] \text {; }
$$




$$
\begin{gathered}
\omega=\left[t_{\text {coolent }}^{\text {inlet }} ; n ; \tau_{\text {operational }}\right] ; \\
A O=\left[t_{\text {coolent }}^{\text {inlet }} ; n\right],
\end{gathered}
$$

where $t_{\text {coolent }}^{\text {inlet }}-$ coolant temperature at the reactor core inlet, ${ }^{\circ} \mathrm{C}$;

$\mathrm{n}$ - neutron flux, particles $/ \mathrm{m}^{2}$;

$\tau_{\text {operational }}-$ operation time, $\mathrm{h}$.

Thus, the objective function takes the form:

$$
J_{\text {min }}=f\left(B\left(t_{\text {coolent }}^{\text {inlet }} ; n ; \tau_{\text {operational }}\right) ; \omega\left(t_{\text {coolent }}^{\text {inlet }} ; n ; \tau_{\text {operational }}\right) ; A O\left(t_{\text {coolent }}^{\text {inlet }} ; n\right)\right)
$$

The method of steepest descent for finding the minimum of the obtained function of three variables is applied below. As a starting point were taken data from nuclear power units operation practice.

Here the algorithm of current $(i=0,1 .$.$) iteration is considered.$

Step 1: To determine the values of the function at the point $M_{i}\left(t_{i} ; n_{i} ; \tau_{i}\right)$ :

$$
J_{\mathrm{i}}=f\left(B\left(t_{i} ; n_{i} ; \tau_{i}\right) ; \omega\left(t_{i} ; n_{i} ; \tau_{i}\right) ; A O\left(t_{i} ; n_{i}\right)\right)
$$

Step 2: To determine the partial derivative of the objective function, using numerical differentiation formula, taking arguments` increments close to zero:

Step 3: To calculate of the antigradient:

$$
\begin{aligned}
& \frac{\partial J}{\partial t}\left(M_{i}\right)=\frac{\Delta J}{\Delta t}\left(M_{i}\right)=\frac{f\left(B\left(t_{i}+\Delta t ; n_{i} ; \tau_{i}\right) ; \omega\left(t_{i}+\Delta t ; n_{i} ; \tau_{i}\right) ; A O\left(t_{i}+\Delta t ; n_{i}\right)\right)-J_{i}}{\Delta t} \\
& \frac{\partial J}{\partial \mathrm{n}}\left(M_{i}\right)=\frac{\Delta J}{\Delta n}\left(M_{i}\right)=\frac{f\left(B\left(t_{i} ; n_{i}+\Delta n ; \tau_{i}\right) ; \omega\left(t_{i} ; n_{i}+\Delta n ; \tau_{i}\right) ; A O\left(t_{i} ; n_{i}+\Delta n\right)\right)-J_{i}}{\Delta n} \\
& \frac{\partial J}{\partial \tau}\left(M_{i}\right)=\frac{\Delta J}{\Delta \tau}\left(M_{i}\right)=\frac{f\left(B\left(t_{i} ; n_{i} ; \tau_{i}+\Delta \tau\right) ; \omega\left(t_{i} ; n_{i} ; \tau_{i}+\Delta \tau\right) ; A O\left(t_{i} ; n_{i}\right)\right)-J_{i}}{\Delta \tau}
\end{aligned}
$$

$$
\begin{aligned}
& d_{t, i}=-\frac{\partial J}{\partial t}\left(M_{i}\right), \\
& d_{n, i}=-\frac{\partial J}{\partial \mathrm{n}}\left(M_{i}\right), \\
& d_{\tau, i}=-\frac{\partial J}{\partial \tau}\left(M_{i}\right),
\end{aligned}
$$

Step 4: To calculate the following $i+1$, argument values:

$$
\begin{aligned}
& t_{i+1}=t_{i}+h_{t} \cdot d_{t, i}, \\
& n_{i+1}=n_{i}+h_{n} \cdot d_{n, i}, \\
& \tau_{i+1}=\tau_{i}+h_{\tau} \cdot d_{\tau, i} .
\end{aligned}
$$

Comment. During the initial step value $h$ for each argument $t_{i} ; n_{i} ; \tau_{i}$ we will accept values considering their physical properties.

For $t_{1}$ - coolant temperature at the reactor core inlet $\mathrm{h}=0,295{ }^{\circ} \mathrm{C}$.

For $n_{1}$ - neutron flux it the reactor core $\mathrm{h}=9 \cdot 10^{4} \mathrm{pcs} / \mathrm{m}^{2}$.

For $\tau_{1}$ - operation time $\mathrm{h}=26352 \mathrm{sec}$.

Step 5: To calculate the value of the objective function in the following $\mathrm{i}+1$ point:

$$
J_{i+1}=f\left(B\left(t_{i+1} ; n_{i+1} ; \tau_{i+1}\right) ; \omega\left(t_{i+1} ; n_{i+1} ; \tau_{i+1}\right) ; A O\left(t_{i+1} ; n_{i+1}\right)\right)
$$

Step 6: To compare function values $J_{i}$ with $J_{i+1}$. For example, if the value $J_{i+1}$ is less than $J_{i}$, the size of the selected step is right, so we can go to step 1 of the algorithm, taking as initial point $M_{i}$ with its coordinates $\left(t_{i+1} ; n_{i+1} ; \tau_{i+1}\right)$. Otherwise, return to step 4 of the algorithm, the new step value $\mathrm{h}:=\mathrm{h} / 2$. For stopping criterion we accept the condition $\left|J_{i+1}-J_{i}\right| \leq \varepsilon$ where $\varepsilon$-given accuracy.

To form a model objective function criteria were separately analyzed the existing NPP control program with VVER-1000 based on the data $[10,11]$. Table 1 summarizes the properties of the considered control programs in terms of impact on the operation of the power plant according to accepted criteria of efficacy, safety and damage. 
Table 1 - Advantages and disadvantages of control programs

\begin{tabular}{|c|c|c|}
\hline $\begin{array}{c}\text { Control program's } \\
\text { name }\end{array}$ & Advantages & Disadvantages \\
\hline $\mathrm{T}_{\mathrm{av}}=\mathrm{const}$ & $\begin{array}{l}\text { - favorable for the } 1 \text { st circuit equipment } \\
\text { due to the stable temperature conditions; } \\
\text { - the possibility of using the temperature } \\
\text { effect to regulate the reactor reactivity; } \\
\text { - operating speed, ease of automation. }\end{array}$ & $\begin{array}{l}\text { - increasing the steam pressure in the steam } \\
\text { generator from the second circuit while reducing } \\
\text { the power unit (deterioration of the strength } \\
\text { characteristics). } \\
\text { - xenon oscillations emergence; } \\
\text { - a large number of unbalanced water; } \\
\text { - input-output of solid absorber leads to a } \\
\text { curvature of the energy release field; } \\
\text { - motion control rods up at border movement in } \\
\text { fuel claddings, located near the control rods } \\
\text { because of the jump in power, there are } \\
\text { significant voltage. }\end{array}$ \\
\hline $\mathrm{P}_{2}=$ const & $\begin{array}{l}\text { - favorable for the } 2 \text { st circuit equipment; } \\
\text { - the possibility of using higher steam } \\
\text { parameters before the turbine at nominal } \\
\text { mode; } \\
\text { - operating speed, ease of automation. }\end{array}$ & $\begin{array}{l}\text { - change in the average temperature of the } \\
\text { coolant limits the unit maneuverability } \\
\text { capabilities and complicates the working } \\
\text { conditions of the pressure automatic control } \\
\text { program in the compensator volume; } \\
\text { - necessity in resizing pressurizer towards } \\
\text { increase; } \\
\text { - increased thermal stresses in the reactor vessel, } \\
\text { fuel claddings; } \\
\text { - an impact on the control rods is required to } \\
\text { compensate the changes in reactivity due to } \\
\text { temperature effect which leads to a distortion of } \\
\text { the field energy release; } \\
\text { - a large number of unbalanced water; } \\
\text { - xenon oscillations emergence; } \\
\text { - motion control rods up at border movement in } \\
\text { fuel claddings, located near the control rods } \\
\text { because of the jump in power, there are } \\
\text { significant voltage. }\end{array}$ \\
\hline $\mathrm{T}_{\mathrm{in}}=\mathrm{const}$ & $\begin{array}{l}\text { - the stability of the nuclear reactor due } \\
\text { to the stable axial offset; } \\
\text { - minimization of the control rods; } \\
\text { - minimum consumption of pure } \\
\text { distillate and boron concentrate; } \\
\text { - reduced amount of unbalance waters; } \\
\text { - improving the working conditions of } \\
\text { fuel; } \\
\text { - the possibility of using temperature } \\
\text { effect for controlling the reactivity of the } \\
\text { nuclear reactor; } \\
\text { - parameters of power distribution } \\
\text { adjustment height with changes in power } \\
\text { do not vary; } \\
\text { - the absence of xenon oscillations. }\end{array}$ & $\begin{array}{l}\text { - large time integration; } \\
\text { - a small control range is limited by permissible } \\
\text { pressure in the steam generator; } \\
\text { - inlet temperature of the coolant in the reactor } \\
\text { increases with increasing pressure in the main } \\
\text { steam collector is strictly limited by the } \\
\text { permissible modes table; } \\
\text { - there is a cyclic variation of the } 2 \text { nd circuit } \\
\text { parameters; } \\
\text { - low speed. }\end{array}$ \\
\hline
\end{tabular}

The simulation results of changes the values of the objective function $\mathrm{J}$ are shown in Figure 1, where point 1 corresponds to the control program switching moment from $\mathrm{T}_{\mathrm{av}}$ to $\mathrm{T}_{\mathrm{in}}$. Point 2 corresponds to the control program switching moment from $\mathrm{T}_{\text {in }}$ to $\mathrm{T}_{\mathrm{av}}$. Point 3 corresponds to the control program switching moment from $\mathrm{T}_{\mathrm{av}}$ to $\mathrm{T}_{\mathrm{in}}$. Point 4 corresponds to the control program switching moment from $T_{\text {in }}$ to $T_{a v}$. Point 5 corresponds to the control program switching moment from $T_{a v}$ to $T_{i n}$. Search results for optimal control of the program showed that during the four years of operation of nuclear fuel in the nuclear power unit with VVER-1000, there are five specific points in the quantitative determination of criteria that show the expediency of switching a control program by changing the configuration of automation systems for Pareto-optimal solutions. 


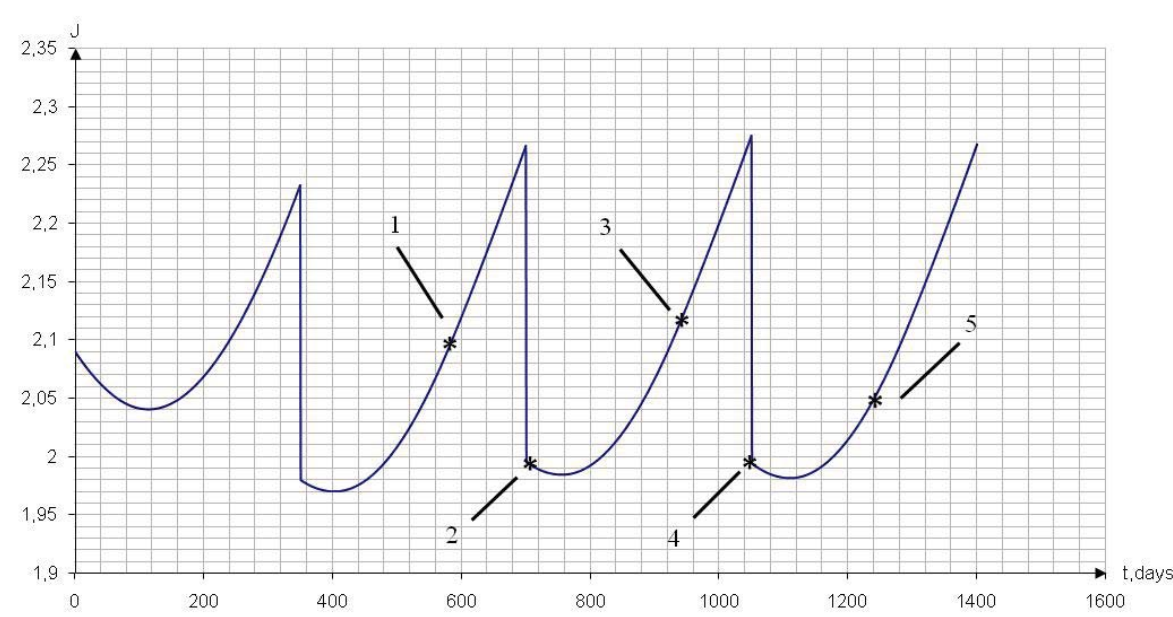

Fig. 1 - Dependence the objective function $J$ optimal values on the NPP operation time with full burning-up of nuclear fuel Conclusions

To search for the best power control program at NPP were used methods of target programming and gradient optimization method. These techniques made it possible to optimize the task and find its Pareto-optimal solution with accuracy.

Search for the best power control program at units with VVER-1000 has identified five specific points in the four-year campaign of nuclear fuel burning-up. Found points are on the line of changes the optimal value of the objective function. Control program $\mathrm{P}_{2}=$ const is not optimal in the analysis.

During the objective function optimization it was revealed that the switching can be carried out only between the two control programs: $\mathrm{T}_{\mathrm{av}}=$ const $и$ и $\mathrm{T}_{\mathrm{in}}=$ const.

References

[1] Pelykh. S.N. Kompleksnyy kriteriy effektivnosti algoritma manevrirovaniya moshchnostyu RU s VVER-1000 v peremennom rezhime / S.N. Pelykh. V.E. Baskakov. T.A. Tsiselskaya // Tr. Odes. politekhn. un-ta.- 2009. - Vyp. 2. - S. $53-58$.

[2] Pelykh. S.N. Analiz ustoychivosti aktivnoy zony VVER-1000 pri razlichnykh programmakh regulirovaniya energobloka / S.N. Pelykh. A.A. Nazarenko. T.A. Tsiselskaya // Tr. Odes. politekhn. un-ta.- 2011. - Vyp. 2(36).- S. $109-114$.

[3] Patent Ukrainy № 59039 na poleznuyu model "Sposob upravleniya yadernoy energeticheskoy ustanovkoy s reaktorom vodyanogo tipa pri izmenenii moshchnosti reaktora ili vneshney nagruzki" / M.V. Maksimov. V.E. Baskakov. T.A. Tsiselskaya. S.N. Pelykh // Ofitsialnyy byulleten "Promislova vlasnist" №8. opublikovan 26.04.2011 g.

[4] Todortsev. Yu.K. Cposob stabilizatsii aksialnogo raspredeleniya neytronnogo polya pri manevrirovanii moshchnostyu VVER-1000 / Yu.K. Todortsev. T.A. Tsiselskaya. M.V. Nikolskiy // Yadernaya i radiatsionnaya bezopasnost. - 2013. № 4. - S. 20-25.

[5] Slipchenko N.I. Optimizatsiya parametrov kremnievyih monokristallicheskih fotopreobrazovateley metodom gradientnogo spuska / N.I. Slipchenko, V.A. Pismenetskiy, A.V. Frolov, V.L. Lukyanenko // Vostochno-Evropeyskiy zhurnal peredovyih tehnologiy. - 2010. - Vyip. № 7 (45) / Tom 3. - P. 41-45.

[6] Golichev I.I. Modifitsirovannyiy gradientnyiy metod naiskoreyshego spuska resheniya linearizovannoy zadachi dlya nestatsionarnyih uravneniy Nave-Stoksa / I.I. Golichev // Ufimskiy matematicheskiy zhurnal. - 2013. - Vyip. № 4 / tom 5. - S. 60-76.

[7] Salihov V.I. Issledovanie metodov optimizatsii protsessa tehnicheskogo osnascheniya predpriyatiy agropromyishlennogo kompleksa / V.I. Salihov, S.A. Vrazhevskiy // Izvestiya vyisshih uchebnyih zavedeniy. Priborostroenie. - 2015. - Vyip. № 9 / tom 58. - S. 770-778.

[8] Maksimov. M.V. A model of a power unit with VVER-1000 as an object of power control / M.V. Maksimov. K.V. Beglov. T.A. Tsiselskaya // Tr. Odes. politekhn. un-ta.- 2012. - Vyp. 1(38). - S. 99 - 105.

[9] Pelykh, S.N. A method for minimization of cladding failure parameter accumulation probability in VVER fuel elements / S.N. Pelykh, M.V. Maksimov, M.V. Nikolsky // Problems of Atomic Science and Technology. Ser. Physics of Radiation Effect and Radiation Materials Science. - 2014. - Iss. 4. - P. 108-116.

[10] Pelykh, S.N. The prediction problems of VVER fuel element cladding failure theory / S.N. Pelykh, M.V. Maksimov, S.D. Ryabchikov // Nuclear Engineering and Design. - 2016. -Vol. 302, Part A, (June). - P. 46-55.

[11] Maksimov M.V. Sposob upravleniya reaktornoy ustanovkoy s VVER-1000 v manevrennom rezhime / M.V. Maksimov. T.A. Tsiselskaya. E.A. Kokol // Problemy upravleniya i informatiki: mezhdunar. nauch.-tekhn. zhurn.-2015. - № 3. - S. $59-75$. 